TITLE:

\title{
Preparation of Al - doped ZnO films by aqueous solution process using a continuous circulation reactor
}

\section{AUTHOR(S):}

Miyake, Masao; Fukui, Hiroshi; Hirato, Tetsuji

\section{CITATION:}

Miyake, Masao ... [et al]. Preparation of Al - doped ZnO films by aqueous solution process using a continuous circulation reactor. Physica Status Solidi (A) Applications and Materials Science 2012, 209(5): 945-948

ISSUE DATE:

2012-05

URL:

http://hdl.handle.net/2433/237673

\section{RIGHT:}

This is the peer reviewed version of the following article: P Physica Status Solidi (A), Volume209, Issue5, May 2012, Pages 945-948], which has been published in final form at https://doi.org/10.1002/pssa.201127385. This article may be used for non-commercial purposes in accordance with Wiley Terms and Conditions for Use of Self-Archived Versions.; The full-text file will be made open to the public on 25 April 2013 in accordance with publisher's 'Terms and Conditions for Self-Archiving'.; この論文は出版社版でありません。引用の際には出版社版をご確認ご利用ください。; This is not the published version. Please cite only the published version. 


\title{
Preparation of Al-doped ZnO films by aqueous solution process using a continuous circulation reactor
}

\author{
Masao Miyake, Hiroshi Fukui, and Tetsuji Hirato* \\ ${ }^{1}$ Graduate School of Energy, Kyoto University, Yoshida-hommachi, Sakyo-ku, Kyoto 606-8501, Japan
}

Received ZZZ, revised ZZZ, accepted ZZZ

Published online ZZZ (Dates will be provided by the publisher.)

Keywords (zinc oxide, impurity doping, carrier concentration, mobility)

* Corresponding author: e-mail hirato.tetsuji.2n@kyoto-u.ac.jp, Phone: +81 75753 5432, Fax: +81 757535453

The fabrication of Al-doped $\mathrm{ZnO}$ films by an aqueous solution process using a continuous circulation reactor was studied. By heating $\mathrm{ZnO}$-saturated ammonia solutions containing 2-10 mM Al( $\left(\mathrm{NO}_{3}\right)_{3}$ with $\mathrm{pH} 10.7$ at $90{ }^{\circ} \mathrm{C}$ under ambient pressure, polycrystalline $\mathrm{ZnO}$ films with $\mathrm{Al}$ content of 1-2 at.\% were deposited. The carrier con- centration of $\mathrm{ZnO}$ films increased with increasing $\mathrm{Al}$ content, indicating that $\mathrm{Al}$ was successfully incorporated into the $\mathrm{ZnO}$ crystals. The Al-doped $\mathrm{ZnO}$ films had carrier concentrations of $10^{19}-10^{20} \mathrm{~cm}^{-3}$ and mobilities of 0.7 to $7 \mathrm{~cm}^{2} \mathrm{~V}^{-1} \mathrm{~s}^{-1}$ after annealing at $300{ }^{\circ} \mathrm{C}$ in air.
1 Introduction Zinc oxide $(\mathrm{ZnO})$ is a transparent oxide semiconductor with a direct bandgap of $\sim 3.3 \mathrm{eV}$, and is a promising material for a wide variety of applications such as transparent conducting films, waveguides, and ultraviolet lasers. A number of vapor phase deposition techniques can be employed to fabricate high-quality $\mathrm{ZnO}$ films, including sputtering [1], pulsed laser deposition (PLD) [2], and metalorganic chemical vapor deposition (MOCVD) [3]. However, aqueous solution processes such as electrochemical deposition [4], chemical bath deposition (CBD) [5], and hydrothermal synthesis [6] have recently attracted more attention owing to their capability to produce large area $\mathrm{ZnO}$ films with low cost and low environmental impact. Recently, Lange's group developed a novel aqueous process using a continuous circulation reactor [7]. This continuous process, taking advantage of retrograde $\mathrm{ZnO}$ solubility with temperature in ammonia solutions, is especially attractive because it enables $\mathrm{ZnO}$ crystals to grow under steady-state conditions. Unlike batch processes as typified by CBD, the reaction conditions such as the concentrations of solutes and $\mathrm{pH}$ do not change during the crystal growth, thereby producing highly-uniform $\mathrm{ZnO}$ films at a constant growth rate.

In this study, we investigated the formation of aluminum-doped $\mathrm{ZnO}$ films through the continuous aqueous so- lution process. The doping of $\mathrm{Al}$ is most widely performed to produce n-type $\mathrm{ZnO}$ films with a low resistivity. Methods for the preparation of $\mathrm{Al}$-doped $\mathrm{ZnO}$ films are well established in the vapor phase deposition processes [1-3] and sol-gel process [8,9], and there have been a few reports on Al-doped ZnO films prepared by CBD [10] and successive chemical solution deposition [11], but no detailed report is available for Al-doping in the continuous aqueous solution process. We prepared Al-doped $\mathrm{ZnO}$ films using ammonia solutions containing various amounts of $\mathrm{Al}\left(\mathrm{NO}_{3}\right)_{3}$, and examined the effect of $\mathrm{Al}\left(\mathrm{NO}_{3}\right)_{3}$ addition on the morphology, Al content, and electrical properties of the resulting ZnO films.

2 Experimental procedure Prior to the $\mathrm{ZnO}$ growth by the aqueous solution process, a $\mathrm{ZnO}$ seed layer was formed on a sapphire substrate $\left(7 \times 7 \mathrm{~mm}^{2}\right)$ by spincoating using a mixture solution of 2-methoxyethanol, 2aminoethanol, and zinc acetate with the mol ratio of 10:1:1 [12]. The spin-coating was performed at $3000 \mathrm{rpm}$, followed by annealing at $300{ }^{\circ} \mathrm{C}$ in air for 1 hour, forming a polycrystalline $\mathrm{ZnO}$ layer with a thickness of $\sim 130 \mathrm{~nm}$. This seed layer was necessary to grow $\mathrm{ZnO}$ films adherent to the substrate. 
The ZnO-saturated ammonia solutions for the growth of $\mathrm{ZnO}$ films were prepared by dissolving $0.95 \mathrm{M}$ (= mol $\left.\mathrm{L}^{-1}\right) \mathrm{NH}_{3}(\mathrm{aq}), 0.05 \mathrm{M} \mathrm{NH}_{4} \mathrm{NO}_{3}$ and $0.5 \mathrm{mM}$ sodium citrate tribasic dihydrate in distilled water. The sodium citrate was added to enhance the lateral growth of $\mathrm{ZnO}$ crystals [13] and thereby to form denser films. If the solutions do not contain citrate ions, $\mathrm{ZnO}$ grows in the form of nanorods. As the source of $\mathrm{Al}$ ions, $\mathrm{Al}\left(\mathrm{NO}_{3}\right)_{3}$ was added into the solution in the concentration range of $0-10 \mathrm{mM}$. The solutions were equilibrated with an excess amount of $\mathrm{ZnO}$ powder in a sealed container under agitation at room temperature $\left(\sim 25{ }^{\circ} \mathrm{C}\right)$ for more than a day. The film growth was carried out using a continuous circulation reactor consisting of two plastic vessels (60 mL each) connected with a silicone tube. The temperature of one of the vessels was kept at room temperature, while the other was heated at $90{ }^{\circ} \mathrm{C}$. The ammonia solution was circulated between the two vessels through the tube and an in-line filter $(0.45 \mu \mathrm{m})$ by a peristaltic pump at the flow rate of $1 \mathrm{~mL} \mathrm{~min}{ }^{-1}$. An excess amount of $\mathrm{ZnO}$ powder was put in the unheated vessel to keep the concentration of $\mathrm{Zn}$ ions constant. The seeded substrate was inserted into the heated vessel, and $\mathrm{ZnO}$ film growth was performed for 5 hours.

The crystallinity and morphology of the resulting films were examined with an X-ray diffractometer (Panalytical, X'PertPRO-MPD PW 3040) and an SEM (Hitachi, X900). The $\mathrm{Al}$ contents in the $\mathrm{ZnO}$ films $(\mathrm{Al} /(\mathrm{Al}+\mathrm{Zn}))$ were determined by EDX. The electrical properties of the $\mathrm{ZnO}$ films were measured with a resistivity/Hall measurement system (Toyo Corporation, ResiTest 8300) using the van der Pauw method at room temperature. For the measurements, $\mathrm{Al}$ ohmic electrodes were formed on the $\mathrm{ZnO}$ films by vacuum evaporation.

3 Results and discussion ZnO films were deposited from the $\mathrm{ZnO}$-saturated ammonia solutions containing $0-10 \mathrm{mM} \mathrm{Al}\left(\mathrm{NO}_{3}\right)_{3}$ by heating at $90{ }^{\circ} \mathrm{C}$. The $\mathrm{pH}$ of the solutions was 10.7 at room temperature. Deposition of $\mathrm{ZnO}$ occurs because the thermodynamic stability of $\mathrm{Zn}\left(\mathrm{NH}_{3}\right)_{4}{ }^{2+}$ ion, which is the dominant species of $\mathrm{Zn}$ ions in the solutions at room temperature, decreases with increasing temperature at this $\mathrm{pH}$, and therefore the solubility of $\mathrm{ZnO}$ decreases. With pH 10.7 and $1.0 \mathrm{M}$ of total ammonia (that is free and combined) concentration, the solubility of $\mathrm{ZnO}$ is thermodynamically calculated to be $0.015 \mathrm{M}$ and $7.5 \times 10^{-5}$ $\mathrm{M}$ at $25^{\circ} \mathrm{C}$ and $90{ }^{\circ} \mathrm{C}$, respectively [14]. On the other hand, $\mathrm{Al}$ ion dissolves in the form of $\mathrm{AlO}_{2}^{-}$, and its solubility should increase with temperature. Thus, the deposition of $\mathrm{Al}$ oxide or hydroxide should not occur independently, but it can be expected that $\mathrm{Al}$ ions are incorporated into the $\mathrm{ZnO}$ crystals during the crystal growth.

Figure 1 shows XRD patterns of the samples prepared from the solutions without and with $10 \mathrm{mM} \mathrm{Al}\left(\mathrm{NO}_{3}\right)_{3}$.
Both patterns show only the $\mathrm{ZnO} 0002$ reflection at $2 \theta=$ $34.5^{\circ}$, indicating that $\mathrm{ZnO}$ crystals with a strong $c$-axis preferred orientation were deposited even from the solution containing $10 \mathrm{mM} \mathrm{Al}\left(\mathrm{NO}_{3}\right)_{3}$.

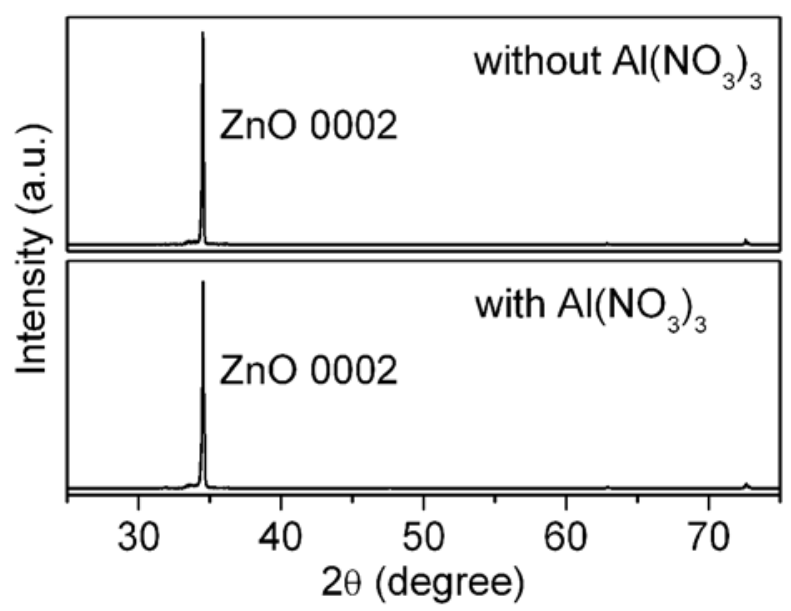

Figure $1 \mathrm{XRD}$ patterns of $\mathrm{ZnO}$ films deposited from ammonia solutions without and with $10 \mathrm{mM} \mathrm{Al}\left(\mathrm{NO}_{3}\right)_{3}$.
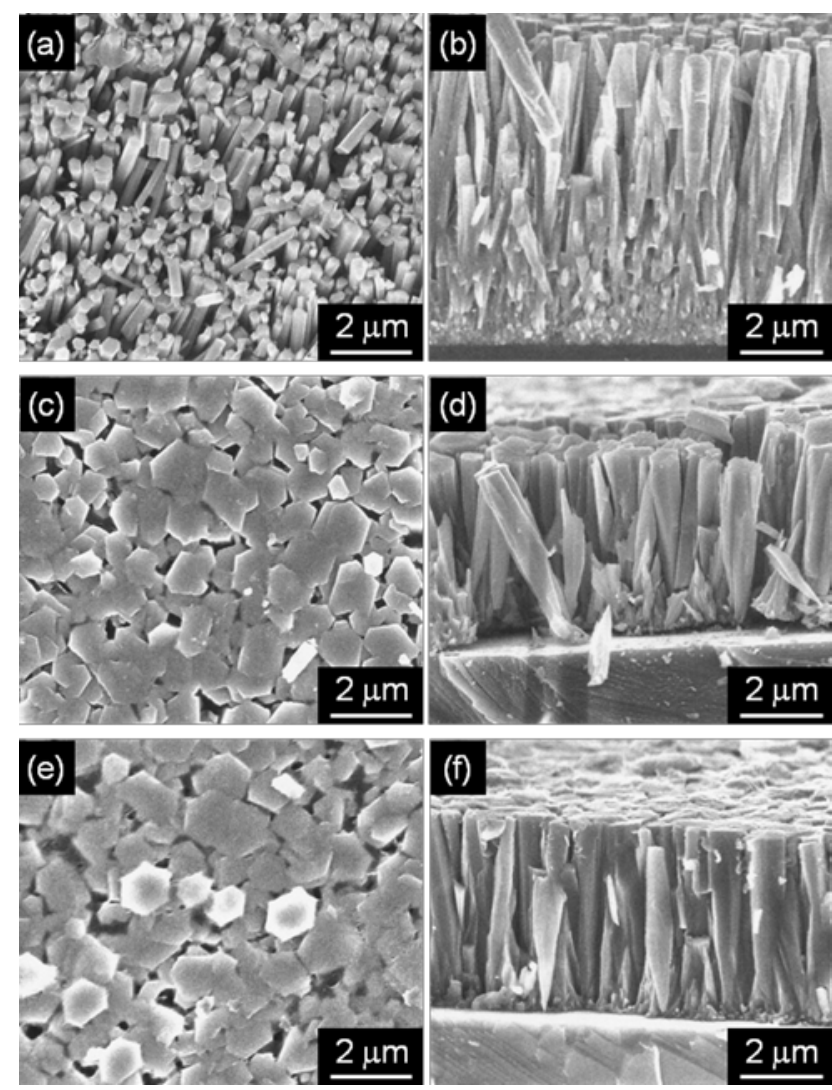

Figure 2 SEM images of $\mathrm{ZnO}$ films deposited from the ammonia solutions containing (a, b) $0 \mathrm{M}$, (c, d) $2 \mathrm{mM}$, and (e, f) $10 \mathrm{mM}$ $\mathrm{Al}\left(\mathrm{NO}_{3}\right)_{3}$. (a, c, e) Top surfaces and (b, d, f) fractured crosssections. 


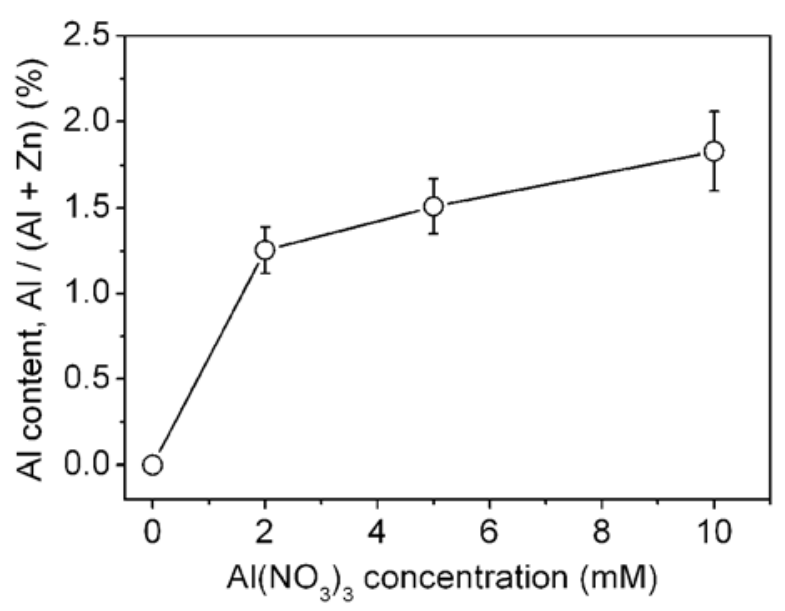

Figure $3 \mathrm{Al}$ content of $\mathrm{ZnO}$ films deposited from the ammonia solutions with various concentrations of $\mathrm{Al}\left(\mathrm{NO}_{3}\right)_{3}$.

Figure 2 presents SEM images of the top surfaces and fractured cross-sections of the $\mathrm{ZnO}$ films deposited from the solutions containing 0,2 and $10 \mathrm{mM} \mathrm{Al}\left(\mathrm{NO}_{3}\right)_{3}$. The SEM images reveal that hexagonal columns of $\mathrm{ZnO}$ crystals grew perpendicularly to the substrate from all the solutions. However, the dimensions of the $\mathrm{ZnO}$ hexagonal columns vary with the addition of $\mathrm{Al}\left(\mathrm{NO}_{3}\right)_{3}$; the diameters and the heights of the $\mathrm{ZnO}$ columns from the solution without $\mathrm{Al}\left(\mathrm{NO}_{3}\right)_{3}$ are $190-280 \mathrm{~nm}$ and $7.7 \mu \mathrm{m}$, respectively, while those with $10 \mathrm{mM} \mathrm{Al}\left(\mathrm{NO}_{3}\right)_{3}$ are $460-650 \mathrm{~nm}$ and $4.8 \mu \mathrm{m}$. That is, the growths in the $a$ - and $c$-directions are promoted and suppressed, respectively, by the addition of $\mathrm{Al}$ ions. This change in the $c / a$-growth ratio is attributable to that $\mathrm{AlO}_{2}{ }^{-}$ions being preferentially adsorbed on the relatively positively charged (0001) surface of $\mathrm{ZnO}$ crystal and suppressing the $\mathrm{ZnO}$ growth in the $c$-direction, as citrate ions do [13].

Composition analysis by EDX confirmed that the $\mathrm{ZnO}$ films from the solutions with $\mathrm{Al}\left(\mathrm{NO}_{3}\right)_{3}$ contained 1-2 at.\% of $\mathrm{Al}$, while the $\mathrm{Al}$ content of the $\mathrm{ZnO}$ without $\mathrm{Al}\left(\mathrm{NO}_{3}\right)_{3}$ was below the detection limit (0.1\%) (Fig. 3). The Al content in the $\mathrm{ZnO}$ film increased with the concentration of $\mathrm{Al}$ ions in the solution.

The electrical resistivity of the as-deposited $\mathrm{ZnO}$ films was lowered by the addition of $\mathrm{Al}\left(\mathrm{NO}_{3}\right)_{3}$ to the solution; while the resistivity of the $\mathrm{ZnO}$ film without $\mathrm{Al}\left(\mathrm{NO}_{3}\right)_{3}$ was $\sim 10^{3} \Omega \mathrm{cm}$, those with $\mathrm{Al}\left(\mathrm{NO}_{3}\right)_{3}$ were $\sim 10 \Omega \mathrm{cm}$ (Fig. $4 \mathrm{a}$ ). The annealing at $300{ }^{\circ} \mathrm{C}$ in air decreased the resistivity of all the $\mathrm{ZnO}$ films by more than two orders of magnitude. Even after the annealing, the resistivities of the $\mathrm{ZnO}$ films from the solutions with $\mathrm{Al}\left(\mathrm{NO}_{3}\right)_{3}$ were lower than that of the non-doped $\mathrm{ZnO}$ film. The minimum resistivity of $3 \times 10^{-}$ ${ }^{2} \Omega \mathrm{cm}$ was obtained when the concentration of $\mathrm{Al}\left(\mathrm{NO}_{3}\right)_{3}$ was $5 \mathrm{mM}$. The sheet resistance of this film with the thickness of $5.8 \mu \mathrm{m}$ was $53 \Omega / \mathrm{sq}$.

The Hall measurements indicated that the $\mathrm{ZnO}$ films have n-type conductions. Figure $4 \mathrm{~b}$ shows the carrier mo-

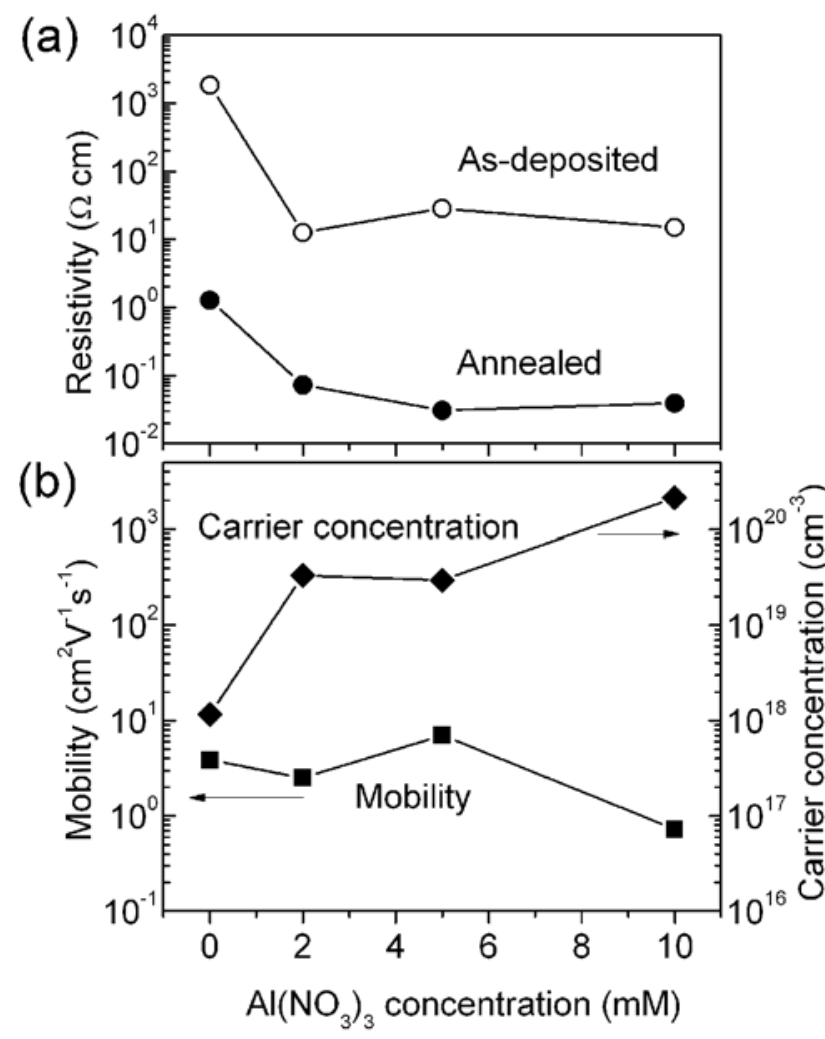

Figure 4 (a) Resistivity, (b) carrier mobility and carrier concentration of $\mathrm{ZnO}$ films deposited from the ammonia solutions with various concentrations of $\mathrm{Al}\left(\mathrm{NO}_{3}\right)_{3}$.

bility and carrier concentration of the $\mathrm{ZnO}$ films after the annealing. The carrier concentration of the $\mathrm{ZnO}$ films increased with increasing concentration of $\mathrm{Al}\left(\mathrm{NO}_{3}\right)_{3}$ and reached $2 \times 10^{20} \mathrm{~cm}^{-3}$, which is two orders of magnitude higher than that of the non-doped $\mathrm{ZnO}$ film $\left(10^{18} \mathrm{~cm}^{-3}\right)$, offering clear evidence that $\mathrm{Al}$ is incorporated into $\mathrm{ZnO}$ crystals from the solutions and works as an donor impurity. The mobility did not vary substantially with the addition of $\mathrm{Al}\left(\mathrm{NO}_{3}\right)_{3}$ up to $5 \mathrm{mM}$, and was in the range of $2.5-7 \mathrm{~cm}^{2}$ $\mathrm{V}^{-1} \mathrm{~s}^{-1}$. However, the mobility decreased to $0.7 \mathrm{~cm}^{2} \mathrm{~V}^{-1} \mathrm{~s}^{-}$ ${ }^{1}$ by the addition of $10 \mathrm{mM} \mathrm{Al}\left(\mathrm{NO}_{3}\right)_{3}$, probably because the ionised impurity scattering became significant [1].

Although the carrier concentration could be increased by the Al-doping, the resistivity obtained in this study is still higher than those reported for Al-doped $\mathrm{ZnO}$ films prepared by the vapor phase deposition processes $\left(\sim 10^{-4} \Omega\right.$ $\mathrm{cm})[1,2]$, mainly because the mobility is smaller in the present films. Since the mobility of the non-doped film prepared by the present process was already small, the primary cause of the small mobility should be the presence of high density of structural defects such as grain boundaries.

3 Conclusions Al-doped polycrystalline $\mathrm{ZnO}$ films were prepared by an aqueous solution process using a continuous circulation reactor at $90{ }^{\circ} \mathrm{C}$. By adding $2-10 \mathrm{mM}$ 
$\mathrm{Al}\left(\mathrm{NO}_{3}\right)_{3}$ to the ammonia solutions, $\mathrm{ZnO}$ films containing 1-2 at.\% Al were deposited. The carrier mobility of the $\mathrm{ZnO}$ films did not vary significantly with the $\mathrm{Al}$ addition and ranged from 0.7 to $7 \mathrm{~cm}^{2} \mathrm{~V}^{-1} \mathrm{~s}^{-1}$. However, the carrier concentration increased with increasing concentration of $\mathrm{Al}\left(\mathrm{NO}_{3}\right)_{3}$ and reached $2 \times 10^{20} \mathrm{~cm}^{-3}$, which was two orders of magnitude higher than that of the non-doped $\mathrm{ZnO}$ film. This result demonstrated that $\mathrm{Al}$ was successfully doped into the $\mathrm{ZnO}$ films by the aqueous solution process.

Acknowledgements The authors thank Mr. Teruyoshi Unesaki and Mr. Kenji Kazumi for their help with the SEM and EDX observations.

\section{References}

[1] T. Minami, H. Sato, H. Nanto and S. Takata, Jap. J. Appl. Phys. Part 2-Letters, 24, L781 (1985).

[2] A. Suzuki, T. Matsushita, N. Wada, Y. Sakamoto and M. Okuda, Jap. J. Appl. Phys. Part 2-Letters, 35, L56 (1996).

[3] M. E. Fragala and G. Malandrino, Microelectronics Journal, 40, 381 (2009).

[4] M. Izaki and T. Omi, Appl. Phys. Lett., 68, 2439 (1996).

[5] T. Hamada, A. Ito, E. Fujii, D. Chu, K. Kato and Y. Masuda, J. Cryst. Growth, 311, 3687 (2009).

[6] D. Andeen, L. Loeffler, N. Padture and F. F. Lange, J. Cryst. Growth, 259, 103 (2003).

[7] J. Richardson and F. Lange, Crystal Growth \& Design, 9, 2576 (2009).

[8] K.-M. Lin, H.-C. Chen, Y.-Y. Chen and K.-y. Chou, J. SolGel Sci. and Tech., 55, 369 (2010).

[9] S. B. Majumder, M. Jain, P. S. Dobal and R. S. Katiyar, Mater. Sci. Eng. B-Solid State Materials for Advanced Technology, 103, 16 (2003).

[10] R. Chandramohan, T. A. Vijayan, S. Arumugam, H. B. Ramalingam, V. Dhanasekaran, K. Sundaram and T. Mahalingam, Materials Science and Engineering B-Advanced Functional Solid-State Materials, 176, 152 (2011).

[11] O. Lupan, S. Shishiyanu, V. Ursaki, H. Khallaf, L. Chow, T. Shishiyanu, V. Sontea, E. Monaico and S. Railean, Solar Energy Materials and Solar Cells, 93, 1417 (2009).

[12] S. Hirano, K. Masuya and M. Kuwabara, J. Phys. Chem. B, 108, 4576 (2004).

[13] D. Andeen, J. Kim, F. Lange, G. Goh and S. Tripathy, Adv. Func. Mater., 16, 799 (2006).

[14] J. Richardson and F. Lange, Crystal Growth \& Design, 9, 2570 (2009). 